Forest Pathology, 2000

30: 7-17

Doi: $\underline{10.1046 / j .1439-0329.2000 .00179 . x}$

\title{
Relationship between presence of basidiomes, above-ground symptoms and root infection by Collybia fusipes in oaks
}

\author{
Benoit Marçais, Olivier Caël, Claude Delatour \\ Laboratoire de Pathologie Forestière. Institut National de la Recherche Agronomique, \\ 54280 Champenoux, France
}

\begin{abstract}
Summary
Collybia fusipes is a common cause of root rot on oak in north of France. C. fusipes basidiomes can be as frequent on oaks in stands where no decline of the trees occurs compared to stands where the decline is chronic. This might be explained by differences in the amount of roots damaged by the parasite. To test that hypothesis, 430 oak trees, Quercus petreæ, Q. robur et $Q$. rubra, located in 6 forests were selected. Half of them showed $C$. fusipes basidiomes at the trunk base. The association between presence of basidiomes and decline of affected trees depended on the forest. The level of infection of each tree by $C$. fusipes, as well as the crown appearance, the tree height / dbh ratio, age and sapwood width were determined. Presence of $C$. fusipes basidiomes was always associated with significant root infections. Trees crown deteriorated with increasing level of root infection and the decline was severe only when the root damage was heavy. However, if the decline of trees heavily damaged by $C$. fusipes was severe in some of the stands, in others, it was only mild. Thus, differences in tree decline between the stands could not be attributed only to differences in root infection severity. Trees damaged by $C$. fusipes were not subjected to a competition higher than their undamaged neighbour as reflected by a similar tree height / dbh ratio.
\end{abstract}

\section{Résumé}

Collybia fusipes est un agent de pourridié fréquent en chênaies. Les carpophores de collybie peuvent être aussi fréquents dans des peuplements de chênes où les arbres ne dépérissent pas que dans des chênaies où le dépérissement est chronique. Ceci pourrait être expliqué par des différences dans l'intensité des dégradations de racines. Pour tester cette hypothèse, 430 chênes, Quercus petreæ, Q. robur et $Q$. rubra, répartis dans 6 forêts ont été sélectionnés. La moitié d'entre eux étaient porteurs de carpophores de collybie. Dans certaines forêts, les arbres porteurs de carpophores de collybie étaient dépérissants alors dans d'autre, ils ne l'était pas. Le niveau d'infection de chaque arbre par la collybie a été déterminé de même que l'état de son houppier et son rapport hauteur / diamètre, son âge et sa largeur d'aubier. Le houppier des arbres infectés se dégrade quand le niveaux d'infection augmente; Le dépérissement n'est prononcé que quand le système racinaire est fortement dégradé par la collybie. Toutefois, si les arbres sévèrement attaqué par la collybie présentent bien un houppier fortement dégradé dans certains des peuplements, dans d'autre, leur couronne reste en relativement bon état. Les différences observées entre les différents peuplement pour ce qui est du dépérissement des arbres ne peuvent donc pas être expliquées par des différences au niveau de l'infection. Les arbres attaqués par la collybie ne paraissaient pas être soumis à une compétition plus forte que leurs voisins sains, car ils avaient un rapport hauteur / diamètre similaire. 


\section{Introduction}

Collybia fusipes (Bull. ex Fr.) Quel. was reported to induce a root rot in oak trees in the last decade (DELATOUR and GUILLAUMIN, 1984; GUILLAUMIN et al, 1985). Therefore, not much data is yet available on the aetiology and epidemiology of this disease. In France, the fungus is often found associated with declining oaks, in particular with pedunculate oak, Quercus robur L., and red oak, Q. rubra L. (DÉPARTEMENT DE LA SANTÉ DES FORÊTS, 1994, MARÇAIS et al, 1998a). Inoculation experiments showed that $C$. fusipes behaves as a primary pathogen, able to infect roots of young vigorous pedunculate and red oaks and healthy mature pedunculate oaks (MARÇAIS and DELATOUR, 1996; MARÇAIS et al, 1998a).

A survey in several forests in the North East of France showed that $C$. fusipes basidiomes are common at the base of oaks, especially in mature stands dominated by pedunculate oak (MARÇAIS et al, 1998a). The fungus was more abundant on the larger, presumably older, trees. Several affected stands, in particular relatively young ones, had been left very dense and competition might have been an important factor in disease development. Presence of $C$. fusipes was not necessarily associated with decline of the affected trees. In two of the surveyed forests, the presence of the fungus was associated with a decline of the trees, while in a third, trees with basidiomes at the base of the trunk seldom had a poor crown. Nevertheless, $C$. fusipes was abundant in all the three forests: in each of them, stands with $30-40 \%$ of the trees infected by $C$. fusipes could be found. A possible explanation could be that, in some situations, $C$. fusipes is abundant, but does not cause much root damage and consequently, has no significant impact on tree health.

To clarify this hypothesis, we selected several forests where the presence of $C$. fusipes was or was not associated with a decline of the trees and studied in more detail the relationship between root infection and the decline status of the tree. We assessed the reliability of fructification as an indicator of $C$. fusipes infection and also compared the age and competition status of infected trees with their healthy neighbours.

\section{Material and Methods}

\subsection{Study sites}

Trees were sampled in six forests from central and north-eastern France. Characteristics of the sites are given in Table 1. Forty-one sites were sampled in La Harth and Amance while just one site was studied in each of the other forests. The stands at Filain and Les Barres suffered from severe competition. Trees in Les Barres were left very dense until the midseventies and then thinned every 5 years. The stand at Filain was left very dense until 1997, when a selective logging was undertaken.

\subsection{Tree sampling}

In Amance, La Harth, Les Aynans and Villey-St-Etienne, oak trees were selected to obtain equivalent numbers of trees with and without basidiomes of $C$. fusipes at the base of the trunk. In Filain, fructification was less abundant so only $20 \%$ of the sampled trees had basidiomes at the base of the trunk. Only dominant or codominant trees were selected. In Amance and La Harth, oak trees with $C$. fusipes basidiomes were located in many stands during a survey for the presence of the pathogen at the forest level. These trees were selected for the present study together with the closest neighbouring oak trees with no $C$. fusipes basidiomes at the trunk base. Two to ten trees were selected at each site, to a total of 102 trees in Amance and 56 trees in La Harth. In Filain, Les Aynans and Villey-StEtienne, 50-66 trees were selected in the same stand. 
In Les Barres, the studied trees were 96 red oaks that had been selected and marked as the dominant trees of the stand in 1974 and had been favoured during the several selective logging programmed in the stand since that time. $C$. fusipes basidiomes had been detected on about half of these trees during the previous 4 years (D. PIOU, personal communication).

\subsection{Determination of the root infection level of the trees}

The number of clumps of $C$. fusipes basidiomes at the base of the trunk was recorded each year in July or August for all trees with the exception of the red oaks at Les Barres. This was done from 1994 to 1997 at Amance, 1995 to 1997 at La Harth, in 1997 at Filain, Les Aynans and Villey-St-Etienne.

Root systems were studied for $C$. fusipes infection as described by MARÇAIS et al (1999). Briefly, the root collar and major roots were partially excavated to a depth of 20-30 $\mathrm{cm}$ and a distance of $80-100 \mathrm{~cm}$ from the trunk base. Lesions caused by $C$. fusipes are very characteristics and are easily detected as patches of dead bark that are orange in colour with small white fans of mycelium scattered within the necrotic tissues. In sessile and pedunculate oak, an hypertrophy of the bark is usually observed as infected bark is thickened up to 3-4 $\mathrm{cm}$. Previous work showed that $C$. fusipes is consistently isolated from such lesions on oak roots (GUILLAUMIN et al, 1985, MARÇAIS et al, 1999). The infection status of each major root was assessed within the following four classes: 0) no necrosis detected; 1) superficial necrosis present, but covering less than half of the root circumference (penetration of $C$. fusipes in the bark of no more than $1-2 \mathrm{~mm}$ ); 2) necrosis covering one side of the root entirely (penetration usually $2-5 \mathrm{~mm}$ for $\mathrm{Q}$. robur); 3) C. fusipes infection over the entire root circumference but root still alive (penetration usually more than $4-5 \mathrm{~mm}$ for $\mathrm{Q}$. robur); 4) root dead with decayed wood. Root diameter was measured at about $10 \mathrm{~cm}$ from the trunk base. The root infection index of a tree was computed as: $\Sigma$ (root diameter $\mathrm{x}$ root rating) $/ \Sigma$ (root diameter). This index therefore takes values from 0 to 4 . Trees with a rating of 0-0.3 will be referred to as "undamaged", having very limited and superficial root lesions. Those with a rating of $0.3-2$ and 2-4 will be referred to as lightly and heavily damaged trees respectively. At les Barres, isolations were attempted on the majority of the trees on which lesions typical of $C$. fusipes were observed. In the others sites, isolations were attempted only whenever lesions not typical of $C$. fusipes were observed. Isolations were performed as described in MARÇAIS et al (1999).

\subsection{Determination of the crown status of the trees}

The appearance of the crown was rated on a 0 to 4 scale adapted from NAGELEISEN (1995): 0) crown healthy and opaque with dense secondary ramification; 1) crown moderately healthy, with dead twigs present and / or gaps present in the canopy; 2) crown moderately declining, with the gaps in the canopy coalescing at the periphery of the crown and forming openings toward the outside in the upper part of the crown; the skeleton of large limbs is fully visible; 3 ) crown severely declining, with large dead limbs in the upper part of the crown and/or loss of more than half of the fine branches; 4) tree dead.

The diameter at breast height (dbh) and the total height of the tree were measured for all trees except in La Harth. The oak species was determined according to the leaf morphology by observing the foliage with binoculars. Wood cores reaching the centre of the trunk were extracted at $1.3 \mathrm{~m}$ above soil level from all the trees except in La Harth. Age and sapwood width were determined. Sapwood width was not determined for the red oaks of Les Barres because the absence of tyloses in red oak wood made it difficult to distinguish sapwood from heartwood. 
Table. 1. Description of the study sites

\begin{tabular}{|c|c|c|c|c|c|c|c|c|}
\hline $\begin{array}{l}\text { Site } \\
\text { (Area in France) }\end{array}$ & $\begin{array}{c}\text { Oak } \\
\text { species }\end{array}$ & $\begin{array}{l}\text { No. } \\
\text { studied } \\
\text { stands }\end{array}$ & $\begin{array}{l}\text { No. } \\
\text { studied } \\
\text { trees }\end{array}$ & Stand origin & Soil texture & $\begin{array}{l}\text { Parental } \\
\text { material }\end{array}$ & Soil pH & Decline history \\
\hline $\begin{array}{l}\text { Amance } \\
\text { (Meurthe-et-Moselle) }\end{array}$ & $\begin{array}{l}\text { Q. petræa } \\
\text { Q. robur }\end{array}$ & 27 & $\begin{array}{l}102 \\
\text { (2-10 per } \\
\text { stand) }\end{array}$ & $\begin{array}{l}\text { Old coppice } \\
\text { with standard }\end{array}$ & Loamy clay & $\begin{array}{l}\text { Calcareous } \\
\text { clay }\end{array}$ & $4.8-6.3$ & No decline \\
\hline $\begin{array}{l}\text { La Harth } \\
\text { (Haut-Rhin) }\end{array}$ & $\begin{array}{l}\text { Q. petræa } \\
\text { Q. robur }\end{array}$ & 14 & $\begin{array}{l}56 \\
(2-10 \text { per } \\
\text { stand })\end{array}$ & $\begin{array}{l}\text { Old coppice } \\
\text { with standard }\end{array}$ & $\begin{array}{l}\text { Sandy loam } \\
\text { with } 20-30 \% \\
\text { stones }\end{array}$ & Gravel & $4.0-5.5$ & $\begin{array}{l}\text { Severe decline of Oak, } \\
\text { Carpinus betulus and Pinus } \\
\text { sylvestris in the early } \\
\text { nineties }\end{array}$ \\
\hline $\begin{array}{l}\text { Filain } \\
\text { (Haute-Saône) }\end{array}$ & $\begin{array}{l}\text { Q. robur } \\
+10 \% \\
\text { Q. petræa }\end{array}$ & 1 & 50 & $\begin{array}{l}\text { Plantation on } \\
\text { agricultural land }\end{array}$ & Loamy clay & Limestone & 5.8 & $\begin{array}{l}\text { Severe decline of } Q \text {. robur } \\
\text { reported in } 1995\end{array}$ \\
\hline $\begin{array}{l}\text { Les Aynans } \\
\text { (Haute-Saône) }\end{array}$ & Q. robur & 1 & 66 & $\begin{array}{l}\text { Old coppice } \\
\text { with standard }\end{array}$ & Sandy loam & Gravel & 4.2 & $\begin{array}{l}\text { Chronic decline for more } \\
\text { than } 10 \text { years }\end{array}$ \\
\hline $\begin{array}{l}\text { Villey-St-Etienne } \\
\text { (Meurthe-et-Moselle) }\end{array}$ & Q. robur & 1 & 60 & $\begin{array}{l}\text { Old coppice } \\
\text { with standard }\end{array}$ & Sandy loam & Gravel & 4.3 & $\begin{array}{l}\text { Chronic decline for more } \\
\text { than } 10 \text { years with high } \\
\text { mortality }\end{array}$ \\
\hline $\begin{array}{l}\text { Les Barres } \\
\text { (Loiret) }\end{array}$ & Q. rubra & 1 & 96 & $\begin{array}{l}\text { Natural } \\
\text { regeneration }\end{array}$ & Sandy loam & Clay & 4.0 & $\begin{array}{l}\text { Chronic decline reported } \\
\text { since the early eighties. } \\
\text { Mortality remains low. }\end{array}$ \\
\hline
\end{tabular}


Table. 2. Characteristics of the studied oak trees depending on their level of infection by Collybia fusipes.

\begin{tabular}{|c|c|c|c|c|c|c|c|c|c|c|c|c|c|c|c|c|c|}
\hline \multirow[b]{2}{*}{$\begin{array}{l}\text { Damage by } \\
\text { C. fusipes } a\end{array}$} & \multicolumn{3}{|c|}{ Amance } & \multicolumn{3}{|c|}{ La Harth } & \multicolumn{2}{|c|}{ Filain } & \multicolumn{3}{|c|}{ Les Aynans } & \multicolumn{3}{|c|}{ Villey-St-Etienne } & \multicolumn{3}{|c|}{ Les Barres } \\
\hline & None & Light & Severe & None & Light & Severe & None & Light & None & Light & Severe & None & Light & Severe & None & Light & Severe \\
\hline $\begin{array}{l}\text { No. of trees } \\
\text { (\% of the trees of } \\
\text { the site) }\end{array}$ & $\begin{array}{c}40 \\
(39)\end{array}$ & $\begin{array}{c}40 \\
(39)\end{array}$ & $\begin{array}{c}22 \\
(22)\end{array}$ & $\begin{array}{l}21 \\
(38)\end{array}$ & $\begin{array}{c}9 \\
(16)\end{array}$ & $\begin{array}{c}26 \\
(46)\end{array}$ & $\begin{array}{c}22 \\
(44)\end{array}$ & $\begin{array}{c}28 \\
(56)\end{array}$ & $\begin{array}{c}20 \\
(30)\end{array}$ & $\begin{array}{c}29 \\
(44)\end{array}$ & $\begin{array}{c}17 \\
(26)\end{array}$ & $\begin{array}{c}18 \\
(30)\end{array}$ & $\begin{array}{c}17 \\
(28)\end{array}$ & $\begin{array}{c}25 \\
(42)\end{array}$ & $\begin{array}{c}38 \\
(40)\end{array}$ & $\begin{array}{c}34 \\
(35)\end{array}$ & $\begin{array}{c}24 \\
(25)\end{array}$ \\
\hline $\begin{array}{l}\text { Mean Root } \\
\text { Infection Index }\end{array}$ & $\begin{array}{c}0.1 \\
(0.0)\end{array}$ & $\begin{array}{c}1.1 \\
(0.2)\end{array}$ & $\begin{array}{c}2.5 \\
(0.2)\end{array}$ & $\begin{array}{c}0.2 \\
(0.1)\end{array}$ & $\begin{array}{c}1.0 \\
(0.3)\end{array}$ & $\begin{array}{l}2.8 \\
(0.2)\end{array}$ & $\begin{array}{c}0.1 \\
(0.0)\end{array}$ & $\begin{array}{c}1.1 \\
(0.2)\end{array}$ & $\begin{array}{c}0.1 \\
(0.1)\end{array}$ & $\begin{array}{c}1.1 \\
(0.2)\end{array}$ & $\begin{array}{c}2.4 \\
(0.2)\end{array}$ & $\begin{array}{c}0.1 \\
(0.1)\end{array}$ & $\begin{array}{c}1.0 \\
(0.2)\end{array}$ & $\begin{array}{c}2.7 \\
(0.2)\end{array}$ & $\begin{array}{c}0.0 \\
(0.0)\end{array}$ & $\begin{array}{c}1.0 \\
(0.2)\end{array}$ & $\begin{array}{l}2.5 \\
(0.2)\end{array}$ \\
\hline $\begin{array}{l}\text { Trunk DBH }(\mathrm{cm}) \\
\text { bc }\end{array}$ & $\begin{array}{c}54 \\
(3.9)\end{array}$ & $\begin{array}{c}53 \\
(4.7)\end{array}$ & $\begin{array}{c}55 \\
(5.3)\end{array}$ & $\begin{array}{l}39.5 \\
(3.9)\end{array}$ & $\begin{array}{l}37.1 \\
(5.8)\end{array}$ & $\begin{array}{l}38.8 \\
(3.9)\end{array}$ & $\begin{array}{c}43 \\
(4.4)\end{array}$ & $\begin{array}{c}43 \\
(2.6)\end{array}$ & $\begin{array}{c}47 \\
(3.0)\end{array}$ & $\begin{array}{c}49 \\
(2.8)\end{array}$ & $\begin{array}{c}50 \\
(4.3)\end{array}$ & $\begin{array}{c}51 \\
(4.1)\end{array}$ & $\begin{array}{c}52 \\
(2.9)\end{array}$ & $\begin{array}{c}50 \\
(3.3)\end{array}$ & $\begin{array}{c}31 \\
(1.6)\end{array}$ & $\begin{array}{c}31 \\
(1.8)\end{array}$ & $\begin{array}{c}29 \\
(2.6)\end{array}$ \\
\hline Height $(m)^{b}$ & $\begin{array}{l}24.8 \\
(0.9)\end{array}$ & $\begin{array}{l}23.2 \\
(0.8)\end{array}$ & $\begin{array}{l}24.3 \\
(1.0)\end{array}$ & - & - & - & $\begin{array}{l}27.2 \\
(0.7)\end{array}$ & $\begin{array}{l}27.5 \\
(0.8)\end{array}$ & $\begin{array}{l}26.3 \\
(0.8)\end{array}$ & $\begin{array}{l}25.5 \\
(0.7)\end{array}$ & $\begin{array}{l}25.1 \\
(1.3)\end{array}$ & $\begin{array}{l}23.1 \\
(0.9)\end{array}$ & $\begin{array}{l}22.5 \\
(1.0)\end{array}$ & $\begin{array}{l}21.8 \\
(0.8)\end{array}$ & $\begin{array}{l}22.6 \\
(0.6)\end{array}$ & $\begin{array}{l}23.1 \\
(0.8)\end{array}$ & $\begin{array}{c}22.16 \\
(0.8)\end{array}$ \\
\hline $\begin{array}{l}\text { Height / DBH } \\
(\mathrm{m} / \mathrm{cm})^{b}\end{array}$ & $\begin{array}{c}0.46 \\
(0.03)\end{array}$ & $\begin{array}{c}0.46 \\
(0.04)\end{array}$ & $\begin{array}{c}0.46 \\
(0.06)\end{array}$ & - & - & - & $\begin{array}{c}0.66 \\
(0.05)\end{array}$ & $\begin{array}{c}0.65 \\
(0.04)\end{array}$ & $\begin{array}{c}0.57 \\
(0.03)\end{array}$ & $\begin{array}{c}0.53 \\
(0.03)\end{array}$ & $\begin{array}{c}0.54 \\
(0.04)\end{array}$ & $\begin{array}{c}0.47 \\
(0.03)\end{array}$ & $\begin{array}{c}0.43 \\
(0.03)\end{array}$ & $\begin{array}{c}0.45 \\
(0.03)\end{array}$ & $\begin{array}{c}0.75 \\
(0.03)\end{array}$ & $\begin{array}{c}0.75 \\
(0.03)\end{array}$ & $\begin{array}{c}0.77 \\
(0.05)\end{array}$ \\
\hline $\begin{array}{l}\text { Sapwood width } \\
(\mathrm{mm})^{b}\end{array}$ & $\begin{array}{l}25.3 \\
(2.7)\end{array}$ & $\begin{array}{l}21.1 \\
(2.1)\end{array}$ & $\begin{array}{l}20.8 \\
(2.8)\end{array}$ & - & - & - & $\begin{array}{l}24.9 \\
(5.9)\end{array}$ & $\begin{array}{l}24.8 \\
(3.6)\end{array}$ & $\begin{array}{l}21.0 \\
(2.9)\end{array}$ & $\begin{array}{l}19.2 \\
(2.2)\end{array}$ & $\begin{array}{l}14.8 \\
(3.1)\end{array}$ & $\begin{array}{l}22.3 \\
(3.1)\end{array}$ & $\begin{array}{l}25.9 \\
(3.7)\end{array}$ & $\begin{array}{l}18.3 \\
(2.4)\end{array}$ & - & - & - \\
\hline Age $b$ & $\begin{array}{l}136 \\
(9)\end{array}$ & $\begin{array}{l}148 \\
(11)\end{array}$ & $\begin{array}{l}146 \\
(13)\end{array}$ & - & - & - & $\begin{array}{l}93 \\
(3)\end{array}$ & $\begin{array}{l}95 \\
(1)\end{array}$ & $\begin{array}{l}117 \\
(7)\end{array}$ & $\begin{array}{l}123 \\
(6)\end{array}$ & $\begin{array}{l}132 \\
(9)\end{array}$ & $\begin{array}{l}121 \\
(6)\end{array}$ & $\begin{array}{l}117 \\
(9)\end{array}$ & $\begin{array}{l}123 \\
(6)\end{array}$ & $\begin{array}{l}62 \\
(2)\end{array}$ & $\begin{array}{l}62 \\
(3)\end{array}$ & $\begin{array}{l}59 \\
(4)\end{array}$ \\
\hline
\end{tabular}

a None, tree healthy or with minor $C$. fusipes infection; Light, root infection index of 0.3 to 2; Severe, root infection index of more than 2.

$\mathrm{b}$ Means (confidence interval at 0.05).

$\mathrm{c}_{\text {Diameter at breast height }}$ 


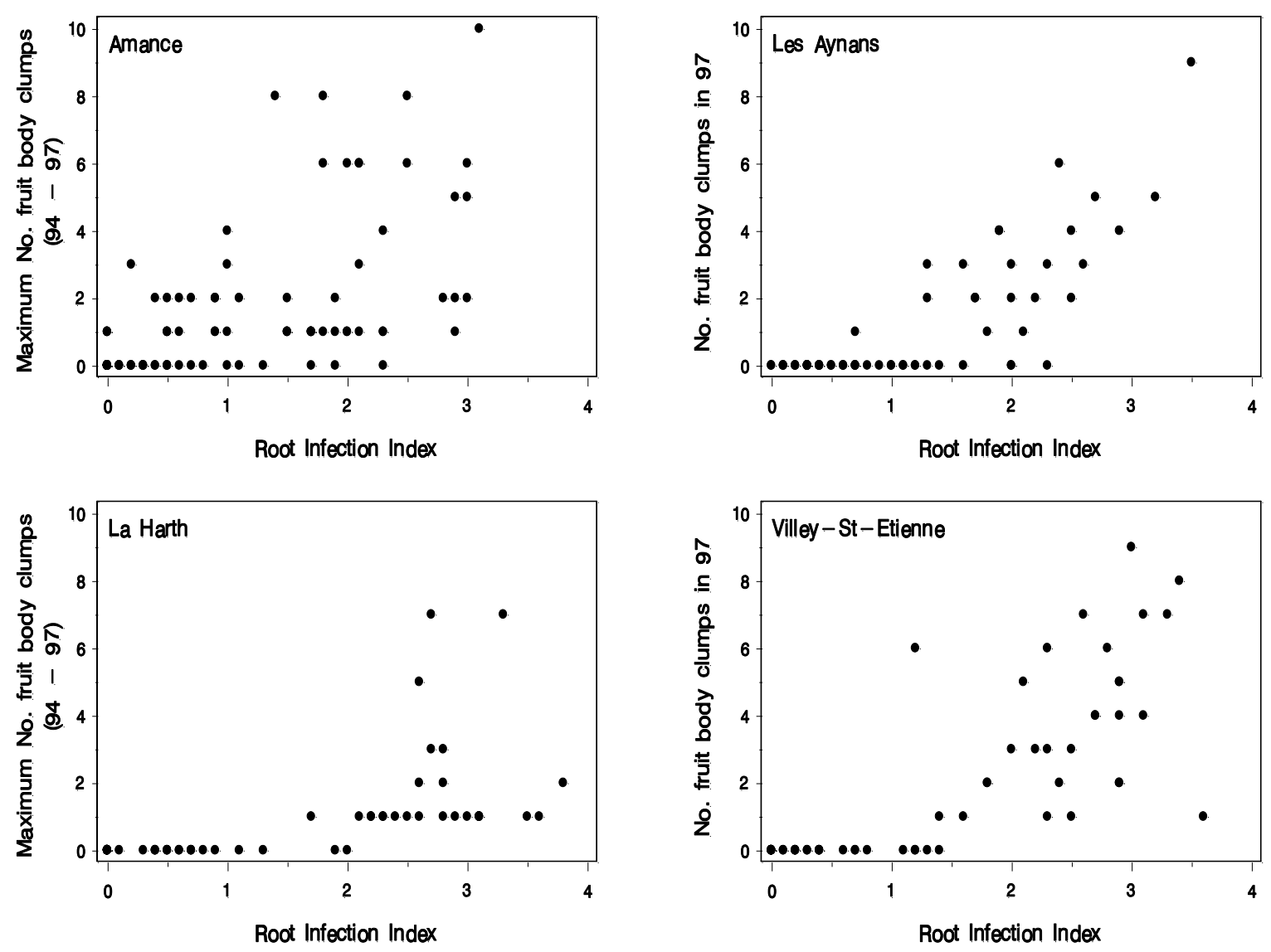

Fig. 1. Relationship between infection of oak root systems by $C$. fusipes and production of basidiomes.

\section{Results}

Trees infected by $C$. fusipes represented approximately $55 \%$ to $70 \%$ of the studied trees, depending on the forest. Severely damaged trees, with a root infection index of more than 2, were less numerous, representing from $25 \%$ of the studied trees in Amance, Les Aynans and Les Barres, to about $45 \%$ in La Harth and Villey-St-Etienne (Table 1). None of the studied trees were severely damaged in Filain. Altogether, 127 Isolations were attempted from 45 of the 58 trees of Les Barres damaged by $C$. fusipes. The parasite was successfully isolated from 43 trees. C. fusipes was isolated in $96 \%$ of the attempts. No other parasite was recovered. Collybia platyphylla was occasionally isolated from very superficial lesions. Four trees in Villey-St-Etienne and one in la Harth had root infections that looked like Armillaria infections, i.e. bark lesion of a brown colour with mycelial fans forming a sheet at the cambium. However, isolations from these trees only yielded $C$. fusipes. Two trees, one in Amance and one in La Harth had atypical lesions. They were very severely attack with a very high proportion of the large roots dead. No hypertrophy of the bark was present and the lesions were of an unusual reddish colour. Although only $C$. fusipes was successfully isolated from those 2 trees, Fistulina hepatica fructifications were found on the collar latter.

Presence of basidiomes of $C$. fusipes at the base of the oak trunk was always associated with significant infection of the tree root system. However, fructification was only a partial indicator for infection as $44 \%$ of the trees showing no Collybia basidiomes in the year of root examination had nevertheless lesions typical of $C$. fusipes root rot. Surveying the presence of basidiomes for 3-4 years in Amance and La Harth did not noticeably improve the information as still $40 \%$ of trees that remained without basidiomes in that period proved to 
be infected. However, $95 \%$ of the trees severely damaged by $C$. fusipes exhibited basidiomes at the trunk base in the year of root examination and numerous clumps of basidiomes indicated severe infections as reflected by a high root infection index (Fig. 1).

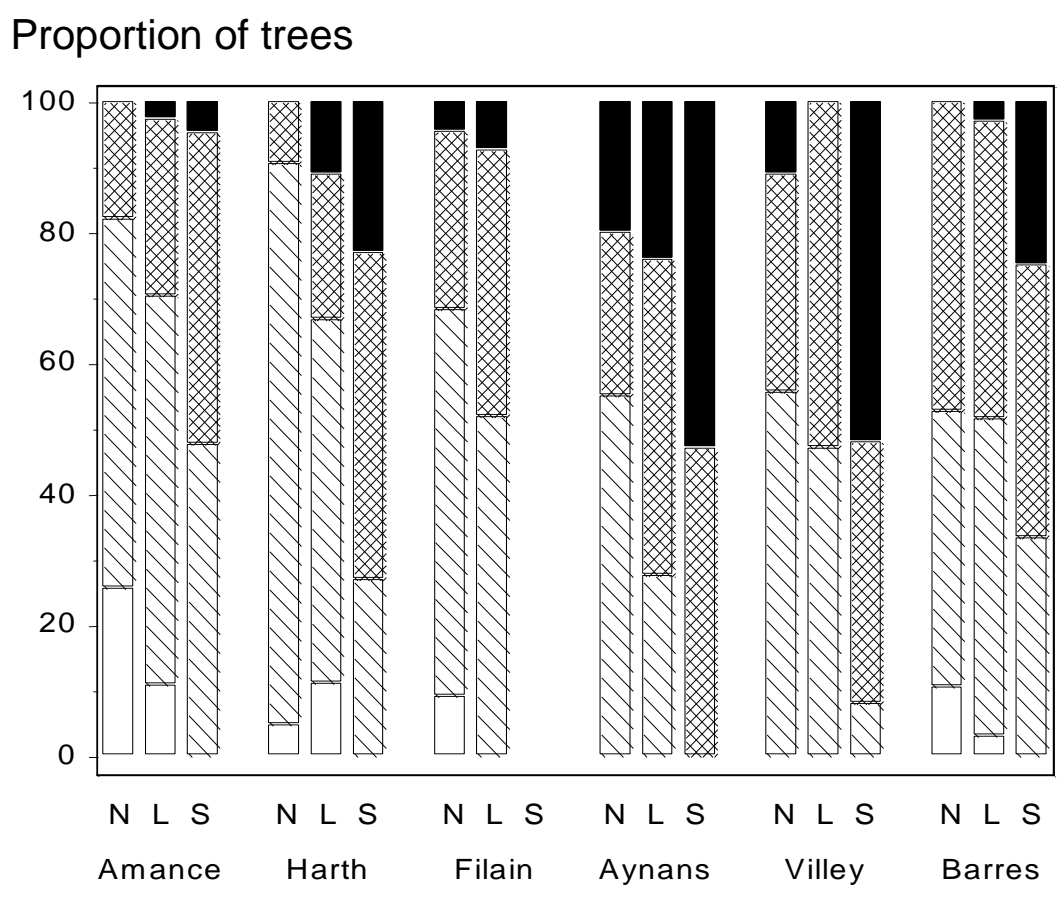

Severity of Root Infection

Fig. 2. Relationship between root infection by $C$. fusipes and appearance of the crown of the oak trees. ( $\square$ ) crown healthy; ( $\square$ ) crown moderately healthy; ( $X)$ ) crown moderately declining; ( ) crown heavily declining. $(\mathrm{N})$ none damaged tree; (L) lightly damaged tree (root infection index of 0.3 to 2); (S) severely damaged tree(root infection index of more than 2).

The crown of the studied oaks tended to deteriorate with increasing levels of root infection (Fig. 2). To have enough numbers for a chi-square analysis, we grouped trees with healthy and moderately healthy crowns and trees with moderately and heavily declining crowns. Differences in crown status between the trees not, slightly or severely damaged by C. fusipes were significant at Les Aynans $\left(\chi^{2}=13.5\right.$, df $\left.=2\right)$, Villey-St-Etienne $\left(\chi^{2}=12.44\right.$, df $=2)$, La Harth $\left(\chi^{2}=18.7, \mathrm{df}=2\right)$, and Amance $\left(\chi^{2}=9.3, \mathrm{df}=2\right)$, but not at Les Barres $\left(\chi^{2}=\right.$ 2.7, $\mathrm{df}=2)$ and Filain $\left(\chi^{2}=1.7, \mathrm{df}=1\right)$. However, the relation between root damage and the crown status was not the same at all sites. In Les Aynans and Villey-St-Etienne, trees severely damaged by $C$. fusipes had a heavily declining crown in about half of the cases, while in Amance, despite a similar mean infection index, trees severely damaged by C. fusipes had a heavily declining crown in only $5 \%$ of the cases (Fig. 2, Table 2). In La Harth and Les Barres, the situation was intermediate between Les Aynans and Amance, with about $25 \%$ of the trees severely damaged by $C$. fusipes having a heavily declining crown.

No differences in trunk diameter ( $\mathrm{dbh}$ ) and tree height existed between trees damaged or not damaged by $C$. fusipes at any of the sites (Table 2). In Filain and Les Barres, where the stands were left very dense, the ratio of tree height to trunk diameter (dbh) was indeed higher than in the other stands. However, infected trees did not have a different height / dbh ratio than their undamaged neighbours. 
In Amance and La Harth, pedunculate oaks had a slightly higher root infection index than sessile oaks ( $1.7 \pm 0.2$ versus $1.3 \pm 0.3$ in Amance and $2.5 \pm 0.2$ versus $1.9 \pm 0.5$ in La Harth). However, as we did not have many infected pedunculate and sessile oaks present together in the same stands, the comparison is not very meaningful.

In Filain, Villey-St-Etienne and Les Barres, there was no difference in age between trees infected by $C$. fusipes and their undamaged neighbours (Table 2). In Amance and Les Aynans, trees infected by $C$. fusipes were about 10 years older than their undamaged neighbours. The difference was significant by student t-test in Les Aynans ( $t=2.14, d f=59$ ), but not in Amance $(t=1.75, \mathrm{df}=91)$. However, in Les Aynans as well as in Amance, just one out of three of the severely damaged trees can be classified as an over mature tree, being more than 150-years.

Sapwood width decreased with the level of infection of affected trees, especially for the severely damaged trees (Table 2). Correlation between the sapwood width and the root infection index was significant at the $5 \%$ level at Amance, Les Aynans and Villey-St-Etienne (Pearson coefficient of correlation of $-0.34,-0.39$ and -0.31 , respectively), but not at Filain where no trees severely damaged by $C$. fusipes were present $(r=-0.19)$. The relationship between sapwood width and root infection index was linear (result not shown).

\section{Discussion}

Although it greatly under estimated the number of infected trees, the survey of C. fusipes basidiomes proved to be an efficient method to detect the presence of the disease at the stand level. This is because, in infected oak stands, the presence of basidiomes was always associated with significant root infections. Moreover, in previous work the large majority of $C$. fusipes basidiomes were found at the base of living trees, and the remaining on stumps and dead trees (MARÇAIS et al, 1998a). As the fungus showed a tendency to fruit each year on the severely infected trees, most of them would be detected by a survey based on the presence of basidiomes. The number of basidiome clumps even gave some information on the severity of the root infection. Thus, differences between the stands in the decline of tree with $C$. fusipes basidiomes could not be attributed only to differences in root infection severity. In this respect, the situation for $C$. fusipes was very different from the situation for Armillaria spp., in particular A. gallica. Basidiomes of Armillaria are often not connected to a particular tree but with colonised dead wood such as stumps or logs. As a result, fruiting usually gives little information on the presence of infection in a stand.

By contrast, the state of the crown was a poor indicator of root infection by $C$. fusipes. Indeed, although the state of the crown often deteriorated with increasing levels of root infection, numerous trees with a root system severely damaged by $C$. fusipes still had good crown condition. Moreover, large differences in the crown state of severely root-damaged trees existed between the different stands. While the crowns of trees severely damaged by C. fusipes clearly declined in Les Aynans and Villey-St-Etienne, they did not in Amance. This discrepancy might indicate that our rating method to estimate the level of root infection on adult trees was inadequate. In a previous test, however, root infection on trees in Les Barres and Les Aynans was estimated using the rating system, and then the trees were totally excavated and the actual amount of root destruction was measured. The rating based on partial excavation gave a good estimate of total root damage (MARÇAIS et al, 1999). $C$. fusipes attacked and killed usually the central part of the root system first and especially the vertical roots beneath the trunk. The large horizontal root were killed only when the infection was very severe and maybe, as a consequence, water conduction and nutrient transport were not strongly affected until late in the infection process. However, the logarithm of the number of both horizontal and vertical living root over one centimetre diameter in a root system decreased with increasing root infection index. 
Presence of other root parasites could not explain the differences in decline status of trees severely infected by $C$. fusipes. Armillaria mellea sensu stricto was known to be present in Les Barres (MARÇAIS et al, 1999) and was fruiting abundantly in Villey-St-Etienne. However, no evidence of lesions induced by this root rot fungus could be detected during the root examination of the studied trees. It was recently proposed that Phytophthora spp. Are involved in oak decline (Jung et al, 1996). Several Phytophthora spp., including P. quercina and $P$. citricola were present in the stands of Amance we studied (Hansen and Delatour, 1999). In those stands, decline of trees heavily damaged by C. fusipes is mild. No Phytophthora could be detected in the soil at the base of 4 declining trees in Les Aynans and 8 in Villey-St-Etienne, though sampling was repeated twice in Les Aynans (Hansen, personal communication). In those 2 stands, decline of trees heavily damaged by $C$. fusipes is severe.

The consequences of severe $C$.fusipes infection were correlated with soil characteristics, and especially water holding capacity. In Les Aynans and Villey-St-Etienne, where severely root-damaged trees were obviously declining, the soil was a sandy loam over a deep layer of gravel and had a limited water holding capacity. By contrast, in stands like Les Barres and Amance where severely infected trees did not decline markedly, the soil parent material was clay with a good water holding capacity. It is possible that the trees were able to withstand much greater loss of roots without obvious visible signs of decline in stands where water was not a limiting factor compared to stands where water shortage occurred occasionally. Alternatively, the development of $C$. fusipes infections could be slower in some sites and the trees could then be able to mitigate the continuous death of roots by production of new adventitious roots. Indeed, adventitious roots commonly develop on oaks infected by C. fusipes (MARÇAIS et al, 1999).

We attempted to estimate the total level of infection in the stands. For this purpose, we used the proportion of trees that had basidiomes at the base of the trunk (results not shown) and the proportion of trees with and without basidiomes that were not, lightly or heavily damaged. For example, In Les Aynans, $18 \%$ of 120 trees in the stand showed fructification and $53 \%$ of the studied trees which did not show fructification were infected by $C$. fusipes. So the estimated proportion of trees infected by $C$. fusipes in this stand was $18+82 \times 0.53$, i.e. $60 \%$. The estimated proportion of trees infected ranged from $40 \%$ in the most affected stands of Amance to $55 \%$ in Filain, $60 \%$ in the most affected stands of La Harth and Les Barres and around $70 \%$ in Villey-St-Etienne. The proportion of trees severely damaged ranged from $10 \%$ in the most affected stands of Amance to $16 \%$ in Les Aynans and about $25 \%$ in Les Barres, Villey-St-Etienne and the most affected stands of La Harth. Thus, $C$. fusipes can be abundant and heavily damaging the root systems of many trees in stands where mortality remains low and decline is only chronic. This is particularly the case within the red oak stand at Les Barres and appears to be a common situation in red oak stands, in particular in the Pyrénée Piemont (DÉPARTEMENT DE LA SANTÉ DES FORÊTS, 1994). $C$. fusipes is abundant in these stands, but the main reported damages are wind thrown trees, not declining trees. As $Q$. rubra is more susceptible to artificial inoculation by $C$. fusipes than $Q$. robur and $Q$. petræa (MARÇAIS, unpublished results), it would be wise to survey red oak stands in Europe to see to which degree they are infected by the parasite.

It is also interesting to note that the location at Filain, where about half of the trees are infected, is a first generation oak stand, planted about a hundred years ago on a former agricultural site. This indicates that Collybia can develop and cause some problems in stands where it was not present at the outset. Previous work strongly suggests that $C$. fusipes spreads by spores (MARÇAIS et al, 1998b) and old forests are present in the immediate vicinity of the Filain stand.

The oak trees infected by $C$. fusipes usually showed crown decline only at advanced stages of root destruction. Many heavily infected tree had a crown in a fair condition, in particular in Amance. For many of them, no obvious cause of stress that could have 
predispose the tree to the infection was found. In particular, trees damaged by $C$. fusipes were not subjected to a different competition compared with their undamaged neighbours and were of a similar trunk diameter. Moreover, at Les Barres, where more detailed information is available (PIOU, DELATOUR and MARÇAIS, in preparation), the trees that are currently the most infected by $C$. fusipes were the most vigorous in 1974 . They were also growing in better soil conditions, with traces of water logging appearing deeper in the soil. This might explain why they were more prone to $C$. fusipes root rot as this fungus seems to be intolerant to anoxia (MARÇAIS, unpublished results).

In a survey at the forest level in several oak forests, including Amance and Les Aynans, basidiomes of $C$. fusipes were shown to be more frequent at the base of larger, presumably older trees (MARÇAIS et al, 1998a). One possibility is that, in old coppice with standard stands, mainly old, over mature, standard trees are infected. From our results, this does not appear to be the case. As severely damaged trees are older, at least in Les Aynans, this may suggest that susceptibility increases with age, or, alternatively, just reflects a longer prolonged development of the disease in older trees.

The trees infected by $C$. fusipes showed a lower current vigour compared to their undamaged neighbours, as reflected by a lower sapwood width. The decrease in sapwood width was proportional to the level of infection. It is difficult from the results to say whether trees with lower vigour were more prone to infection or if infection decreased the vigour. Artificial inoculation shows that $C$. fusipes behaves as a primary pathogen, developing on vigorous young sapling and adult trees (MARÇAIS and DELATOUR, 1996, MARÇAIS et al, 1998a). However, it is still possible that trees stressed by unfavourable soil conditions such as drought or, in the case of $Q$. petræa and $Q$. robur, defoliation by insects result in an increased susceptibility to $C$. fusipes infection.

\section{Acknowledgements}

We want to thank G. Maréchal and F. Cecconi for their technical assistance and E. Hansen for reviewing the manuscript. We also want to thank D. Piou (ENGREF, Arboretum des Barres), the Cemagref for their help at Les Barres, the Office National des Forêts for its help at Les Aynans, Amance, Villey-St-Etienne and Filain and the observatoire de La Harth for its help at La Harth. This work was done thanks to the support of the Office National des Forêts, France.

\section{Reference}

Delatour, C.; Guillaumin, J.J., 1984: Un pourridié méconnu : le Collybia fusipes (Bull. ex Fr.) Quel. Compte-rendu de l'Académie d'Agriculture de France 70, 123-126.

DEPARTEMENT DE LA SANTE DES ForETS (France), 1994: La santé des forêts (France) en 1993. Ministère de l'Agriculture et de la pèche (DERF-DSF)

Guillaumin, J. J.; Bernard, C.; Delatour, C.; Belgrand, M., 1985: Contribution à l'étude du dépérissement du chêne : pathologie racinaire en forêt de Tronçais. Ann. Sc. For. 42, 1-22.

Hansen, E., Delatour, C., 1999. Phytophthora species in oak forests of North-East France. Ann. Sc. For. (in press, July issus)

JUNG, T.; BlaschKe, H.; NeUmann, P., 1996: Isolation, identification and pathogenicity of Phytophthora species from declining oak stands. Eur. J. For. Path. 26, 253-272

MARÇAIS, B.; DelatouR, C. 1996: Inoculation of Oak (Quercus robur and Q. rubra) with Collybia fusipes. Plant disease 80, 1391-1394.

MARÇAIS, B.; CAËL, C.; DelatouR, C. 1998a: Investigation on the distribution and impact of Collybia fusipes in oak forest. In: C. Delatour, J.J. GUILLAUMin, B. Lung-ESCARMANT and B. MARÇAIS (ed.), Proceedings of the ninth International Conference on Root and Butt Rots of Forest Trees, Colloques de I'INRA n 89, France, pp. 215-222. 
MarÇais, B., MARTIN, F., Delatour, C., 1998b: Structure of Collybia fusipes population in two infected oak stands. Mycol. Res. 102, 361-367.

MARÇAis, B.; CAËL, O.; Delatour, D. 1999: Measuring the impact of Collybia fusipes on the root system of oak trees. Ann. Sc. For. 56, 227-236

NAGELEISEN, L. M. 1995: Méthode d'évaluation de l'aspect du houppier (protocole DEPEFEU). Département de la santé des forêts, Echelon technique Nord-Est, 11pp 